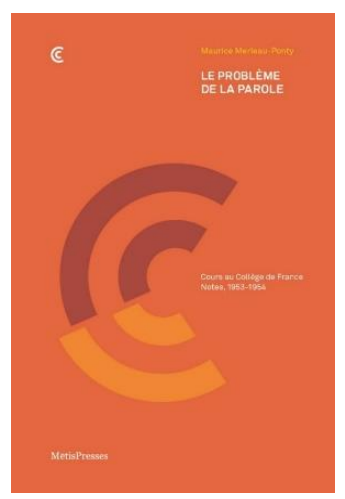

RESENHA: MERLEAU-PONTY, Maurice. Le problème de la parole: cours au Collége de France, notes, 1953-1954. Genève: MētisPresses, 2019, 28op, ISBN: 9782-940563-6o-9

\title{
Merleau-Ponty e o mistério da fala
}

\section{CLAUDINEI APARECIDO DE FREITAS DA SILVA ${ }^{1}$}

Cuidadosamente estabelecido, sob os cuidados de Emmanuel de Saint Aubert, contendo, ainda, um Prefácio de Lovisa Andén e um Posfácio de Franck Robert, o presente texto trazido, à lume, pela MētisPresses de Genève, Le problème de la parole: cours au Collége de France, notes, 1953-1954 corresponde a mais um projeto de longo alcance a ser encampado pela reportada editora suíça, a exemplo, portanto, de Le monde sensible et le monde de l'expression (2011), de Recherches sur l'usage littéraire du langage (2013) e de Entretiens avec Georges Charbonnier et autres dialogues (2016).

Le problème de la parole é constituído por três formatos: i) notas preparatórias de curso; ii) projetos e planos de curso e, por fim, iii) notas de trabalhos que Maurice Merleau-Ponty redigira no biênio correspondente (dezembro de 1953 e abril de 1954), no Collège de France. A bem da verdade, esse rico material, até então inédito, é uma extensão daqueles dois primeiros anunciados acima que formam as lições ministradas no ano anterior no mesmo Collège.

Neste curso, Merleau-Ponty explora o sentido de um discurso que emerge do sensível: questionando os processos de aquisição da linguagem, bem como as patologias que a afetam, o filósofo propõe uma interpretação original da linguística de Saussure além de fornecer um grande comentário acerca da obra de Proust. Em ambos, como no estudo da afasia e do aprendizado de línguas em

\footnotetext{
1 Professor Doutor do Colegiado de Graduação e Pós-Graduação (Scricto sensu) em Filosofia da UNIOESTE. E-mail: cafsilva@uol.com.br.
} 
Jakobson e Goldstein, Merleau-Ponty analisa os poderes criativos e instituintes da fala, poderes que a literatura traz à tona de maneira exemplar.

Sob esse espectro, O problema da fala delineia, por assim dizer, uma filosofia da instituição e uma ontologia que questiona o advento do sentido no entrelaçamento do sensível e da expressão. Isso, pois, mostra a importância deste percurso sem precedentes: apresentando uma das primeiras leituras filosóficas de Saussure e Proust, constitui também uma etapa essencial na evolução do pensamento merleau-pontyano que pode lançar luz quanto ao significado de sua ontologia última. Isso porque o próprio Merleau-Ponty via na experiência da linguagem um poder de significação ontológica, algo que a tradição metafísica no Ocidente, por exemplo, não conferiu o devido estatuto haja vista que a linguagem não passava de um mero instrumento, uma técnica pura e simples pela qual o pensamento ou o espírito transmitia as ideias. A linguagem fora tomada pela cultura filosófica clássica como um meio mnemônico, um veículo sonoro pelo qual as ideias podiam ser decodificadas e socialmente comunicadas. Ora, bem ao contrário, Merleau-Ponty situa a linguagem como não subsidiária ao intelecto, uma vez que não há, para ele, uma sobredeterminação do pensar sobre o falar, uma vez que pensamento e linguagem perfazem uma só relação dialética de relacionamento mútuo. Mais: sem se reduzir a um objeto puro e simples, a linguagem exprime o ser.

Esse aspecto acima reivindicado pela obra de Merleau-Ponty projeta a linguagem como um fenômeno misterioso à medida que ela radica uma estrutura dinâmica, ou se quiser, uma Gestalt. Dito de outro modo, a linguagem sempre comporta uma estrutura móvel de figura e fundo. Há uma relação íntima entre o dizível e o indizível, já que, entre eles, há uma espécie de contrapartida secreta.

É sob esse escopo que, em rigor, fenomenologicamente falando, não há, em acepção própria, um "problema” da fala, mas um “mistério". Esse mistério é constitutivo da linguagem à medida que a reabre permanentemente. Quer dizer, o mistério é o que encerra a experiência do dito e do não-dito como silêncio. A linguagem é inesgotável; nossas palavras ditas por mais que as empreguemos de forma versátil nunca abarcam, por inteiro, o sentido; sentido esse que transcende os signos convencionais que formam determinada língua. Esse sentido transcendente rente aos significantes se manifestam também sob uma dimensão pragmática da linguagem; algo, aliás, convergente àquilo que o chamado "segundo Wittgenstein" dera vazão em suas Investigações filosóficas. Essa convergência de princípio, admitida claramente por Merleau-Ponty em seu memorável encontro com Ryle, sela sobre o quanto todo esse debate fenomenológico cruza, em parte, com a virada linguística operada pela escola de Oxford como segunda vertente da filosofia analítica.

Submissão: 28. 02. 2021 / Aceito: 30. 05. 2021 